\title{
Temperature-induced recovery of Vibrio cholerae from the viable but nonculturable state: growth or resuscitation?
}

\author{
Jacques Ravel, ${ }^{1}$ Ivor T. Knight, ${ }^{2}$ Catherine E. Monahan, ${ }^{2}$ Russell T. Hill \\ and Rita R. Colwell ${ }^{1,3}$
}

Author for correspondence: Rita R. Colwell. Tel: +1 301403 0501. Fax: +1 3014548123.

\footnotetext{
1 Center of Marine Biotechnology, University of Maryland Biotechnology Institute, 600 East Lombard St, Baltimore, MD 21202, USA

2 Department of Biology, James Madison University, Harrisonburg, VA 22807, USA

3 University of Maryland Biotechnology Institute, 4321 Hartwick Road, Suite 500, College Park, MD 20740, USA
}

\begin{abstract}
Vibrio cholerae cells were incubated at $4{ }^{\circ} \mathrm{C}$ in nutrient-limited artificial seawater (ASW) microcosms. Plate counts declined from $8 \times 10^{5}$ to less than 2 c.f.u. $\mathrm{ml}^{-1}$ in about $23 \mathrm{~d}$. When samples of microcosms were shifted to $30{ }^{\circ} \mathrm{C}$, plate counts increased to $2.2 \times 10^{5}$ c.f.u. $\mathrm{ml}^{-1}$ in $72 \mathrm{~h}$. An experiment was performed to determine whether culturable cells obtained after temperature upshifts were the result of 'resuscitation', or outgrowth, of nonculturable cells or of cell division and growth of the few culturable cells that remained in samples. Prior to temperature upshift, samples from the microcosms were diluted 10- and 100-fold in filter-sterilized $(0.1 \mu \mathrm{m})$ ASW from the microcosms. Undiluted, 1/10, and 1/100 diluted samples recovered culturability to about 2.2 $\times 10^{5}$ c.f.u. $\mathrm{ml}^{-1}$ within $72 \mathrm{~h}$ of temperature upshift. If resuscitation of nonculturable cells had occurred, the resultant number of culturable cells in diluted samples would have been 1/10 and 1/100 that of undiluted samples, respectively. In microcosms where plate counts had declined to less than 1 c.f.u. $\mathrm{ml}^{-1}, 1 / 100$ diluted samples did not regain culturability, i.e. no culturable cells remained from which growth could occur. Our conclusions are that in the experiments reported here, recovery of culturable cells on temperature upshifts resulted from growth and that there were no growthinhibiting factors in the spent growth medium, supported by the finding that about $10^{2}$ recovered $V$. cholerae cells $\mathrm{ml}^{-1}$ inoculated into filter-sterilized microcosm ASW grew to about 6.2 $\times 10^{5}$ c.f.u. $\mathrm{ml}^{-1}$ in $24 \mathrm{~h}$, confirming that $V$. cholerae is capable of significant growth in ASW.
\end{abstract}

Keywords: Vibrio cholerae, viable but nonculturable cells, regrowth, resuscitation

\section{INTRODUCTION}

Discoveries of the past decade have revealed the existence of a dormant state into which Vibrio cholerae enters, in response to environmental parameters such as temperature and salinity (Xu et al., 1982), and nutrient deprivation (Baker et al., 1983). Colwell and co-workers have suggested that $V$. cholerae can enter a state where the cells are viable but nonculturable (Xu et al., 1982; Brayton \& Colwell, 1987; Colwell et al., 1990). In this state, cells are reduced in size, become ovoid and, in contrast to starved cells, cannot be grown using conventional bacteriological techniques. The existence of a viable but nonculturable

Abbreviations: AODC, acridine orange direct counts; ASW, artificial seawater; DVC, direct viable counts. state, in response to adverse environmental conditions, has been observed for Gram-negative bacteria, for example, Escherichia coli (Xu et al., 1982; Byrd \& Colwell, 1990), Vibrio vulnificus (Linder \& Oliver, 1989; Nilsson et al., 1991), Salmonella enteritidis (Roszak \& Colwell, 1987), Aeromonas salmonicida (Allen-Austin et al., 1984), Shigella sonnei and Shigella flexneri (Colwell et al., 1985), Shigella dysenteriae (Islam et al., 1993; Rahman et al., 1994), Helicobacter (Campylobacter) jejuni (Rollins \& Colwell, 1986), and Helicobacter pylori (Shahamat et al., 1993).

Methods described by Kogure et al. (1979) and Zimmermann et al. (1978) are useful in demonstrating that dormant cells retain viability, even though these cells are nonculturable on conventional media. It has been concluded that the phenomenon is a bacterial survival mechanism, with entry into the viable but nonculturable 
state being influenced by environmental parameters such as temperature, salinity and nutrient concentration, with species and strain variations also being reported (Roszak \& Colwell, 1987). Moreover, it has been shown that viable but nonculturable cells remain potentially pathogenic. The existence of a viable but nonculturable state for $V$. cholerae may be an important and fundamental ecological consideration in worldwide epidemics of $V$. cholerae (Colwell et al., 1990; Epstein et al., 1993).

Inability to detect viable cells by conventional microbiological plating or inoculation into enrichment media has stimulated investigations on recovery of cells from the viable but nonculturable state. Addition of nutrient was used by Roszak et al. (1984) to recover S. enteritidis. Recently, Kaprelyants \& Kell (1993) used rich liquid medium to recover nonculturable Micrococcus luteus cells from long-term storage in spent growth medium and using flow cytometric analysis concluded that resuscitation of M. luteus had occurred. Nilsson et al. (1991) reported that the estuarine pathogenic bacterium $V$. vulnificus can recover from the viable but nonculturable state, without nutrient addition, by responding to a temperature upshift from $4{ }^{\circ} \mathrm{C}$ to room temperature $\left(23^{\circ} \mathrm{C}\right)$. They concluded that this temperature upshift induced nonculturable cells to recover from the viable but nonculturable state to the original cell number. Nilsson $e t$ al. (1991) concluded that recovery of culturable cells was due to resuscitation of these cells rather than growth of a few remaining culturable cells.

Following the experimental protocol of Nilsson et al. (1991), we have now shown that viable but nonculturable $V$. cholerae cells underwent the same 'recovery' when the incubation temperature was shifted up to $30^{\circ} \mathrm{C}$ after incubation at $4{ }^{\circ} \mathrm{C}$. However, we also performed experiments to distinguish between true resuscitation and apparent resuscitation resulting from regrowth of a small number of $V$. cholerae cells that remained culturable. In addition, we investigated the ability of $V$. cholerae to grow in a very low nutrient medium.

\section{METHODS}

Strains and microcosm conditions. Two strains of Vibrio cholerae were used in these studies: a streptomycin-resistant derivative of $V$. cholerae $569 \mathrm{~B}$, and $V$. cholerae CVD101, a tox $A$ mutant of $V$. cholerae 395 (Kaper et al., 1984). $V$. cholerae was incubated at $37^{\circ} \mathrm{C}$ in Luria-Bertani (LB) broth (Maniatis et al., 1982 ) and harvested at an $\mathrm{OD}_{600}$ of $0 \cdot 8-1 \cdot 0$ by centrifugation at $1400 \mathrm{~g}$ for $5 \mathrm{~min}$. Cells were washed sequentially at room temperature in $5 \%(\mathrm{w} / \mathrm{v}) \mathrm{LB}\left(\mathrm{NaCl} 5 \mathrm{~g} \mathrm{l}^{-1}\right), 1 \% \mathrm{LB}(\mathrm{NaCl}$ $5 \mathrm{~g} \mathrm{l}^{-1}$ ), and twice in 10 p.p.t. artificial sea water (ASW) (Instant Ocean, Aquarium Systems) to prevent carry-over of nutrients on inoculation of microcosms. ASW contains undetectable concentrations of organic carbon (R. Studt, Aquarium Systems, personal communication). Cells were recovered after each wash by centrifugation ( $1400 \mathrm{~g}$ for $5 \mathrm{~min}$ ). During this washing procedure, cells were held for $1 \mathrm{~h}$ in the $1 \% \mathrm{LB}$ wash. In order to obtain an accurate cell count, $1 \mathrm{ml}$ of a $10^{-4}$ dilution was stained with $100 \mu \mathrm{l} 0 \cdot 1 \%$ acridine orange (Sigma) and the cells were collected by filtration through a $0.2 \mu \mathrm{m}$ black filter (Poretics) according to the procedure of Hobbie et al. (1977). Cells were inoculated at about $10^{5}$ cells $\mathrm{ml}^{-1}$ in $100 \mathrm{ml} 10$ p.p.t.
ASW in pre-cooled $250 \mathrm{ml}$ flasks. The flasks had been scrupulously cleaned by overnight soaking in a $5 \%(\mathrm{v} / \mathrm{v})$ solution of RBS35 detergent (Pierce), followed by 30 rinses in deionized distilled water and overnight treatment in $5 \mathrm{M} \mathrm{HCl}$, followed by a further 30 rinses. Flasks were filled with deionized distilled water, autoclaved and emptied prior to addition of sterile 10 p.p.t. ASW. The microcosms were incubated at $4{ }^{\circ} \mathrm{C}$ in the dark. Microcosms were prepared in duplicate for $V$. cholerae 569B, and in triplicate for $V$. cholerae CVD101.

Cell counts. Samples taken at the time of incubation (time 0 ) and at subsequent time intervals were monitored by plate counts, acridine orange direct counts (AODC) and direct viable counts (DVC). Plate counts were obtained by spreading appropriate dilutions of $V$. cholerae onto LB agar. Plates were incubated at $30^{\circ} \mathrm{C}$, and colonies were counted after $2 \mathrm{~d}$. Total bacterial counts were performed by AODC, as described by Hobbie $e t$ al. (1977). Cells were counted at a magnification of $1000 \times$ using an Olympus Vanox AHBT epifluorescent microscope. Counting was done manually and approximately 300-700 bacteria per filter were counted. Direct viable counts were done by a modification of the procedure of Kogure et al. (1979). Samples were enriched to a final concentration of $0.25 \%(\mathrm{w} / \mathrm{v})$ yeast extract in the presence of $15 \mu \mathrm{g}$ nalidixic acid $\mathrm{ml}^{-1}$ and incubated for $24 \mathrm{~h}$ at $30^{\circ} \mathrm{C}$ in the dark with shaking. Elongated cells were counted by epifluorescent microscopy, as described for AODC. Both total counts and direct viable counts were recorded.

Microscopic observation. Morphological changes of $V$. cholerae cells were monitored as the cells entered the viable but nonculturable state at $4{ }^{\circ} \mathrm{C}$, as well as 'recovery' at $30^{\circ} \mathrm{C}$ by AODC.

Temperature upshift experiments. Triplicate microcosms of $V$. cholerae CVD101 in 10 p.p.t. ASW were prepared following the methods described above. Plate counts and AODC were monitored periodically. At eight time points (4, 7, 14, 17, 20, 24,28 and $33 \mathrm{~d}$ ), $10 \mathrm{ml}$ subsamples were removed to sterile polypropylene $15 \mathrm{ml}$ tubes for incubation at $30^{\circ} \mathrm{C}$ in the dark without shaking. Plate counts in these subsamples were determined daily for $4 \mathrm{~d}$, with the exception of the last two time points, which were monitored for $6 \mathrm{~d}$.

Dilution and temperature upshift experiments. Microcosms were monitored until the plate counts decreased to 2 c.f.u. $\mathrm{ml}^{-1}$. Ten millilitre samples of the microcosms were filtered through $0.2 \mu \mathrm{m}$ membrane filters (Millipore), and the filters were placed 'face up' (side with collected cells) onto LB agar. Colonies were counted after $48 \mathrm{~h}$. Samples from microcosms were diluted in 10 p.p.t. ASW to give $1 / 10$ and $1 / 100$ dilutions. The 10 p.p.t. ASW diluent was obtained from original microcosms in which the $V$. cholerae cells had entered the viable but nonculturable state and was rendered cell-free by filtration through a $0 \cdot 1 \mu \mathrm{m}$ filter. Experiments were done in a final volume of $5 \mathrm{ml}$ in $50 \mathrm{ml}$ sterile polypropylene tubes. The incubation temperature for the $1 / 10$ and $1 / 100$ dilutions and a $5 \mathrm{ml}$ undiluted control was shifted to $30^{\circ} \mathrm{C}$. Tubes were incubated in the dark without shaking. Plate counts and total cell counts were monitored as described above. In order to show that the diluent used did not contain any cells which were able to recover culturability after the temperature upshift, $5 \mathrm{ml}$ samples of the $0.2 \mu \mathrm{m}$-filtered microcosms were incubated at $30^{\circ} \mathrm{C}$, and plate counts were done. Also, the effect of the subsampling procedure on recovery was followed by maintaining and monitoring a $5 \mathrm{ml}$ subsample in the dark at $4^{\circ} \mathrm{C}$.

Growth at very low nutrient concentrations. Using the method described above, $10^{3}$ or $10^{2}$ cells $\mathrm{ml}^{-1}$ were inoculated into $5 \mathrm{ml}$ filter-sterilized 10 p.p.t. ASW. Quadruplicate micro- 
cosms were incubated at $30^{\circ} \mathrm{C}$ in the dark without shaking. Plate counts were monitored on LB medium for $4 \mathrm{~d}$.

Ten-microlitre samples of a recovered microcosm containing $6.7 \times 10^{5}$ c.f.u. $\mathrm{ml}^{-1}$ were inoculated into $10 \mathrm{ml}$ sterile 10 p.p.t. ASW and into $0 \cdot 1 \mu \mathrm{m}$ filter-sterilized 10 p.p.t. ASW from a microcosm in which cells had entered the viable but nonculturable state. These were incubated at $30^{\circ} \mathrm{C}$ for $3 \mathrm{~d}$. Samples were removed periodically to determine culturability by plating on tryptic soy agar (Difco).

Reproducibility of results. Entry into the viable but nonculturable state was monitored in duplicate or triplicate microcosms and results are presented as a mean value \pm SD. Dilution experiments were done in duplicate subsamples from duplicate microcosms and results shown are the mean of four subsamples. Homogeneity of the variance was calculated using the Fisher's Protected LSD test at the significance level of 0.05. Statistical analyses were performed with the Superanova program (Abacus Concepts). Populations in different microcosms and subsamples were considered to be not significantly different if $P>0.05$.

\section{RESULTS}

\section{Viable but nonculturable state of $V$. cholerae in ASW}

Microcosms were prepared in duplicate and incubated in ASW (salinity 10 p.p.t.) at $4{ }^{\circ} \mathrm{C}$ with an initial inoculum of about $10^{6}$ cells $\mathrm{ml}^{-1}$. The viable but nonculturable response of $V$. cholerae 569B is shown in Fig. 1 . After $26 \mathrm{~d}$, plate counts in duplicate microcosms had decreased to $\leqslant 1.7$ c.f.u. $\mathrm{ml}^{-1}$, while the total direct count increased slightly from $7.6 \times 10^{5}$ cells ml ${ }^{-1}$ to $8.3 \times 10^{5}$ cells ml $^{-1}$. Although the culturable count was less than two culturable cells $\mathrm{ml}^{-1}$, the viable count as determined by DVC (Kogure et al., 1979) was still at least $2.8 \times 10^{4}$ cells $\mathrm{ml}^{-1}$, indicating that the cells were in the viable but nonculturable state as described by Colwell $e t$ al. (1985).

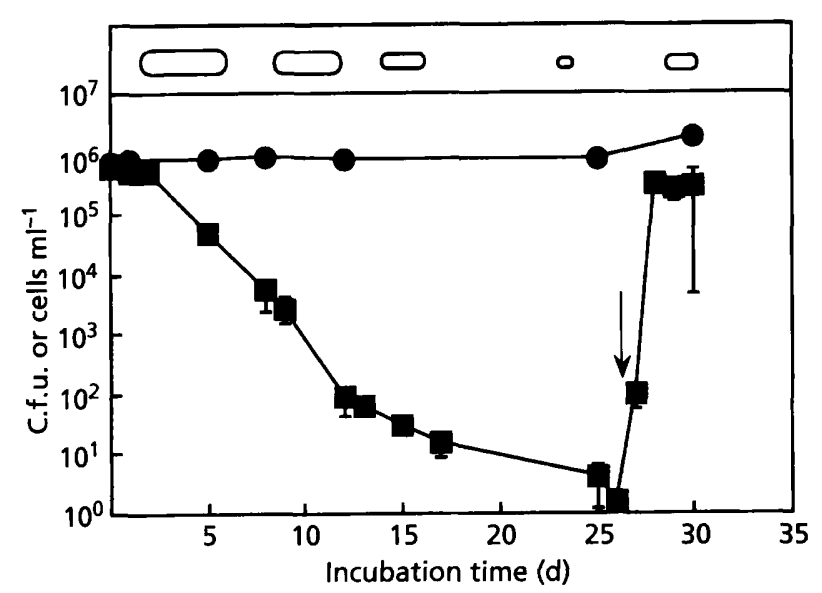

Fig. 1. Entry of $V$. cholerae 569B into the viable but nonculturable state at low temperature $\left(4^{\circ} \mathrm{C}\right)$, and recovery after temperature upshift from $4{ }^{\circ} \mathrm{C}$ to $30^{\circ} \mathrm{C}$. Changes in cell morphology during the entry of $V$. cholerae into the viable but nonculturable state and recovery are shown at the top. The arrow indicates temperature upshift from $4{ }^{\circ} \mathrm{C}$ to $30^{\circ} \mathrm{C}$. Total cell count determined by AODC; $\square$, plate counts on LB. Results are means from duplicate experiments \pm SD.

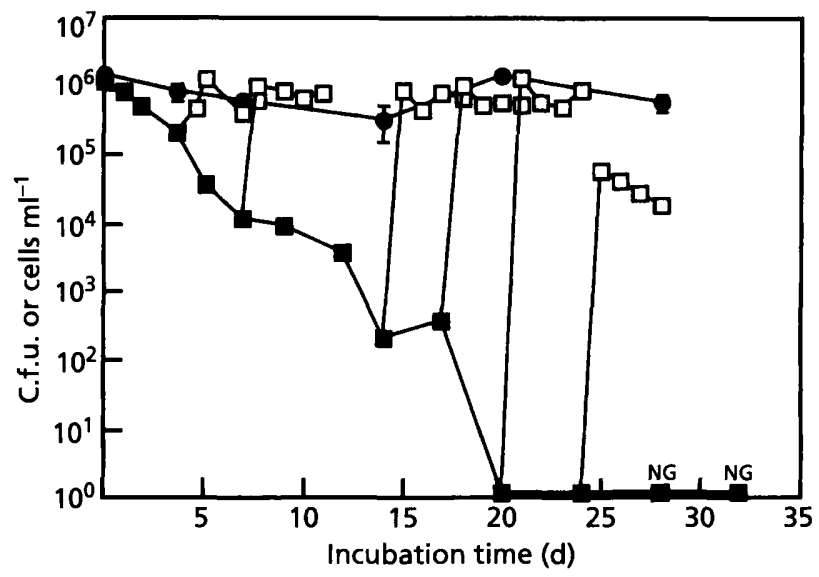

Fig. 2. Plate counts of $V$. cholerae CVD101 incubated at $4{ }^{\circ} \mathrm{C}$ in 10 p.p.t. ASW ( $\square$ ) and recovery of mini-microcosm samples by temperature upshift from $4{ }^{\circ} \mathrm{C}$ to $30^{\circ} \mathrm{C}(\square)$. $A O D C$ of samples from the microcosm. NG, no growth upon temperature upshift. Results are means of triplicate experiments \pm SD.

Samples of these microcosms containing an average of 1.7 culturable cells $\mathrm{ml}^{-1}$ were shifted from an incubation temperature of $4{ }^{\circ} \mathrm{C}$ up to $30^{\circ} \mathrm{C}$. After incubation for $3 \mathrm{~d}$ at $30^{\circ} \mathrm{C}, V$. cholerae $569 \mathrm{~B}$ cells had recovered culturability because $3.2 \times 10^{5}$ cells ml ${ }^{-1}$ were culturable (Fig. 1). Longer incubation at $30^{\circ} \mathrm{C}$ did not increase the culturable count further and an insignificant decrease was observed from $3.2 \times 10^{5}$ to $2.9 \times 10^{5}$ c.f.u. $\mathrm{ml}^{-1}$ after two more days.

Viable but nonculturable $V$. cholerae CVD101 cells showed the same response as $V$. cholerae 569B when incubated in 10 p.p.t. ASW and shifted from $4{ }^{\circ} \mathrm{C}$ to $30^{\circ} \mathrm{C}$. $V$. cholerae CVD101 cells were used in an experiment where recovery by temperature upshift was assessed at eight time points during entry into the viable but nonculturable state. Fig. 2 shows the response of $V$. cholerae CVD101 cells in microcosms when incubated in 10 p.p.t. ASW at $4{ }^{\circ} \mathrm{C}$, and subsamples subsequently incubated at $30^{\circ} \mathrm{C}$. Cells became nonculturable after $20 \mathrm{~d}$. Subsamples processed at $28 \mathrm{~d}$ and $33 \mathrm{~d}$ did not recover from the viable but nonculturable state after $6 \mathrm{~d}$, an observation similar to that of H.-S. Xu \& R. R. Colwell who found that much longer incubation is required (unpublished data).

\section{Dilution and temperature upshift experiments}

In order to investigate whether recovery by temperature upshift was due to true resuscitation or to growth of a few culturable cells of $V$. cholerae 569B which remained in the microcosms, dilution experiments were done. The initial number of culturable cells in microcosms was about 1.7 cells ml$^{-1}$ (Table 1 ). If resuscitation of all viable but nonculturable cells had occurred, plate counts in $1 / 10$ and 1/100-diluted samples would be expected to recover to $1 / 10$ and $1 / 100$ of the level in the undiluted sample, respectively. However, growth from a small number of 
Table 1. AODC and plate counts of $V$. cholerae 569B after temperature upshift from $4{ }^{\circ} \mathrm{C}$ to $30^{\circ} \mathrm{C}$ for undiluted samples, and samples diluted $1 / 10$ and $1 / 100$ in filter-sterilized ASW

Means from undiluted samples were obtained from duplicate experiments and those from diluted samples were from quadruplicate experiments.

\begin{tabular}{|c|c|c|c|c|c|c|}
\hline \multirow{2}{*}{$\begin{array}{l}\text { Time } \\
\text { at } \\
30^{\circ} \mathrm{C} \\
\text { (h) }\end{array}$} & \multicolumn{2}{|c|}{ Undiluted } & \multicolumn{2}{|c|}{$1 / 10$ dilution } & \multicolumn{2}{|c|}{ 1/100 dilution } \\
\hline & $\begin{array}{c}\text { AODC } \\
\left(\text { cells } \mathrm{ml}^{-1}\right)\end{array}$ & $\begin{array}{l}\text { Plate count } \\
\text { (c.f.u. } \mathrm{ml}^{-1} \text { ) }\end{array}$ & $\begin{array}{c}\text { AODC* } \\
\left(\text { cells } \mathrm{ml}^{-1}\right)\end{array}$ & $\begin{array}{l}\text { Plate count } \dagger \\
\text { (c.f.u. } \mathrm{ml}^{-1} \text { ) }\end{array}$ & $\begin{array}{c}\text { AODC* } \\
\left(\text { cells } \mathrm{ml}^{-1}\right)\end{array}$ & $\begin{array}{l}\text { Plate count } \dagger \\
\text { (c.f.u. } \mathbf{m l}^{-1} \text { ) }\end{array}$ \\
\hline 0 & $8.2 \times 10^{5}$ & $1.7 \times 10^{0}$ & $8.2 \times 10^{4}$ & $1.7 \times 10^{-1}$ & $8.2 \times 10^{3}$ & $1.7 \times 10^{-2}$ \\
\hline 20 & & $0.9 \times 10^{2}$ & & $4.9 \times 10^{2}$ & & $6.5 \times 10^{1}$ \\
\hline 91 & $1.9 \times 10^{6}$ & $2.9 \times 10^{5}$ & $1.8 \times 10^{6}$ & $2 \cdot 1 \times 10^{5}$ & $1.7 \times 10^{6}$ & $4.3 \times 10^{5}$ \\
\hline
\end{tabular}

*Values at time 0 were deduced from the AODC of the undiluted sample.

† Values at time 0 were deduced from the plate count of the undiluted sample.

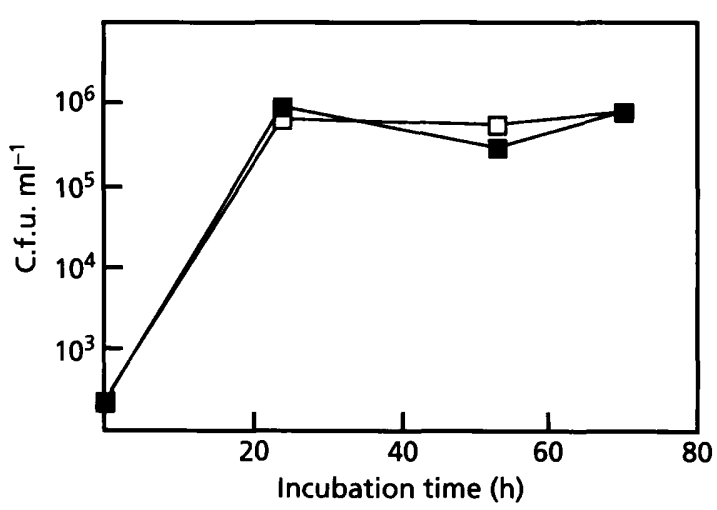

Fig. 3. Plate counts of recovered V. cholerae CVD101 cells incubated at $30^{\circ} \mathrm{C}$ in 10 p.p.t. ASW ( $\square$ ) and filter-sterilized microcosm 10 p.p.t. ASW ( $\square$ ). Results are means of duplicate experiments \pm SD.

cells that had remained culturable would give an increase in plate counts in all three samples to approximately the same number of cells, since nutrients available in each sample would be similar. Results from this experiment are shown in Table 1. After $67 \mathrm{~h}$, plate counts in undiluted $1 / 10$ - and 1/100-diluted samples were all at about $2 \cdot 2 \times 10^{5}$ c.f.u. $\mathrm{ml}^{-1}$. The increase in the total cell count was similar for all three samples after incubation for $91 \mathrm{~h}$ at $30^{\circ} \mathrm{C}$ (Table 1). Dilutions were performed in quadruplicate; and one of the 1/100-diluted samples did not recover culturability and is not included in Table 1. A similar experiment was performed with microcosms which contained about $0 \cdot 1$ culturable cells $\mathrm{ml}^{-1}$. In this case $1 / 100$ and 1/1000 dilutions were tested and after incubation for up to $6 \mathrm{~d}$, no cells recovered culturability in these diluted samples, although the undiluted control recovered to a platable count of $2 \cdot 1 \times 10^{5}$ c.f.u. $\mathrm{ml}^{-1}$ after incubation for $3 \mathrm{~d}$, and the total cell count increased from $8.9 \times 10^{5}$ cells $\mathrm{ml}^{-1}$ to $1.5 \times 10^{6}$ cells $\mathrm{ml}^{-1}$ in $6 \mathrm{~d}$.

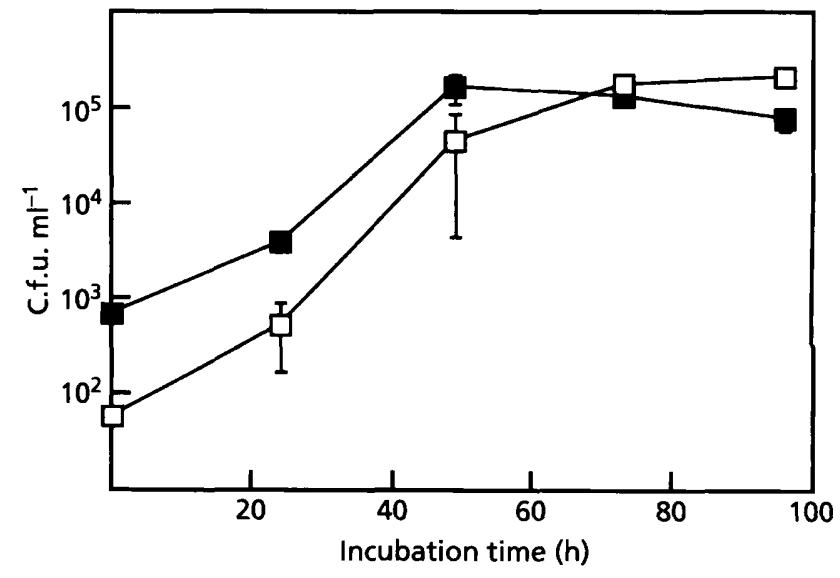

Fig. 4. Plate counts of $V$. cholerae $569 \mathrm{~B}$ cells incubated at $30^{\circ} \mathrm{C}$ in filter-sterilized 10 p.p.t. ASW. Cells were inoculated at concentrations of about $10^{2}(\square)$ or $10^{3}(\square)$ cells $\mathrm{ml}^{-1}$. Results are means of duplicate experiments \pm SD.

\section{Growth at very low nutrient concentrations}

To test growth of $V$. cholerae cells under the very low nutrient conditions present in microcosms, recovered $V$. cholerae CVD101 cells were inoculated into filtersterilized 10 p.p.t. ASW from a microcosm in which cells had entered the viable but nonculturable state, and in fresh 10 p.p.t. ASW. Fig. 3 shows growth to $2.5 \times 10^{2}$ c.f.u. $\mathrm{ml}^{-1}$ of recovered $V$. cholerae cells in $10 \mathrm{ml}$ fresh 10 p.p.t. ASW and filtered-sterilized microcosm ASW : cell growth occurred in both media. After $24 \mathrm{~h}$ the plate count had reached $6.2 \times 10^{5}$ c.f.u. $\mathrm{ml}^{-1}$, and no further increase was obtained after incubation for $3 \mathrm{~d}$ at $30^{\circ} \mathrm{C}$.

Growth of $V$. cholerae $569 \mathrm{~B}$ was assessed in 10 p.p.t. ASW at $30^{\circ} \mathrm{C}$. Growth curves obtained from microcosms inoculated with $10^{3}$ or $10^{2}$ cells $\mathrm{ml}^{-1}$ are shown in Fig. 4. 
As assessed by plate counts, $1-2 \times 10^{5}$ c.f.u. $\mathrm{ml}^{-1}$ were detectable in both microcosms after $4 \mathrm{~d}$.

\section{DISCUSSION}

$V$. cholerae $569 \mathrm{~B}$ cells entered the viable but nonculturable state after about $24 \mathrm{~d}$ when incubated at $4{ }^{\circ} \mathrm{C}$ in 10 p.p.t. ASW. In a previous study (unpublished results), $V$. cholerae was found to enter this state more rapidly at $4{ }^{\circ} \mathrm{C}$ than at $25^{\circ} \mathrm{C}$. These results and the seasonality observed in the detection of $V$. cholerae in the environment (Chowdhury et al., 1992) indicate an important role of temperature and salinity for entry into the viable but nonculturable state by $V$. cholerae. Nilsson et al. (1991) recovered $V$. vulnificus, an estuarine bacterium, from the viable but nonculturable state, using only a temperature upshift from $4{ }^{\circ} \mathrm{C}$ to room temperature $\left(23^{\circ} \mathrm{C}\right)$. They described this phenomenon as 'resuscitation' from the viable but nonculturable state. This was the first report of recovery of viable but nonculturable cells without addition of nutrient, and suggested that temperature may be the single most important factor in resuscitation from the viable but nonculturable state in some species of bacteria, at least for $V$. vulnificus. Subsequently, it was shown that on incubation at low temperatures $V$. vulnificus apparently produces a factor that causes a decline in culturability, but a few cells retain the ability to grow, and the 'resuscitation' reported previously was probably regrowth from the few culturable cells, rather than resuscitation per se (Weichart et al., 1992).

We investigated the response of $V$. cholerae to a temperature upshift from $4{ }^{\circ} \mathrm{C}$ to $30^{\circ} \mathrm{C}$. Nonculturable $V$. cholerae cells regained culturability from $1 \cdot 7$ c.f.u. $\mathrm{ml}^{-1}$ to $3.2 \times 10^{5}$ c.f.u. $\mathrm{ml}^{-1}$, after incubation for $3 \mathrm{~d}$ at $30^{\circ} \mathrm{C}$ (Fig. 1). These results were similar to those obtained by Nilsson et al. (1991), who showed that even if $V$. vulnificus did not respond to nutrient downshift like $V$. cholerae at $25^{\circ} \mathrm{C}$ (Wolf \& Oliver, 1992), both organisms recovered from the viable but nonculturable state after only a temperature upshift from $4{ }^{\circ} \mathrm{C}$ to room temperature. Changes in morphology of $V$. cholerae cells observed during the entry into the viable but nonculturable state in this study are similar to those published more than ten years ago ( $\mathrm{Xu}$ et al., 1982; Baker et al., 1983) and to those reported for $V$. vulnificus (Nilsson et al., 1991). After incubation in very low nutrient medium (10 p.p.t. ASW), $V$. cholerae underwent morphological change and typical commashaped cells transformed into small cocci as shown in Fig. 1. However, upon resuscitation, none of the $V$. cholerae cells reverted back to the original rod shape, but remained coccoid, although a slight increase in size was observed (Fig. 1).

Methods that have been proposed to enumerate viable cells include the reduction of $p$-iodonitrotetrazolium violet (INT) to INT-formazan by the electron transport system of metabolizing cells (Zimmermann et al., 1978) and the DVC method (Kogure et al., 1979). A problem with the INT assay is that it is difficult to detect formazan crystals in the very small, viable but nonculturable cells, such as those observed in this study. In the DVC method, yeast extract and nalidixic acid are added to samples and after incubation elongated cells can be readily observed and are counted as viable cells. This method gives an estimate, through direct examination, of the number of viable cells in a population and is convenient to use when processing many samples. However, in some cases, as in this study, the bacteria appeared only slightly swollen but not clearly elongated. It is likely that under certain conditions the DVC method underestimates the number of viable cells present. Variability in response, based on concentration of yeast extract and nalidixic acid, has been reported (Roszak et al., 1984), and a study of this very point was made by Peele \& Colwell (1981). A method using the fluorescent redox probe 5-cyano-2,3-ditolyltetrazolium chloride (Rodriguez et al., 1992) is presently under investigation for detection of viable $V$. cholerae cells in laboratory microcosms and appears to give good results.

Because it was unclear, in our view, whether the $V$. cbolerae cells did indeed revert to the culturable state by temperature upshift alone, we investigated whether $V$. cholerae cells were responsive to temperature upshift throughout entry into the viable but nonculturable state. $V$. cholerae cells recovered from the viable but nonculturable state at all time points tested (Fig. 2). However, after $8 \mathrm{~d}$ in the nonculturable state $(28 \mathrm{~d}$ after the commencement of the experiment), no cells were recovered after temperature upshift. One explanation for this observation is that no culturable cells were present in the subsample mini-microcosm taken at these particular time points. This suggested the hypothesis, that in such cases, a few culturable cells are necessary in order to observe recovery from the viable but nonculturable state, and indicated that cell division from a few remaining culturable cells may be a requirement for recovery of culturable cells after temperature upshift.

Thus, experiments were designed explicitly to determine whether recovery from temperature upshift was due to resuscitation or to division of the few culturable cells that remained. Samples of nonculturable microcosms were diluted in filter-sterilized microcosm 10 p.p.t. ASW. The same number of culturable cells was obtained after temperature upshift in 10- and 100-fold dilutions and in undiluted control samples after incubation for $2 \mathrm{~d}$ at $30{ }^{\circ} \mathrm{C}$, indicating that growth had occurred during the process of recovery and that there was no inhibiting factor in the spent growth medium. This experiment demonstrated that growth occurred during the temperature upshift, but does not exclude the possibility that resuscitation of viable but nonculturable cells occurred as the first step in the recovery process. Cells could recover by reverting to a culturable state by resuscitation and then grow to reach the maximum carrying capacity of the medium, in this case about $2 \cdot 4 \times 10^{5}$ c.f.u. $\mathrm{ml}^{-1}$. However, when samples from a microcosm where only $0 \cdot 2$ cells $\mathrm{ml}^{-1}$ were culturable were diluted 100 -fold, no recovery of culturable cells was observed after $6 \mathrm{~d}$. Furthermore, one of the quadruplicate samples in the initial dilution experiment did not recover, possibly because no culturable cells remained in this particular sample, i.e. 
extinction dilution occurred. Thus, it is concluded from this study with $V$. cholerae that the presence of a small number of culturable cells is required for recovery to occur by temperature upshift alone.

In some cases, recovery occurred from dilutions in which less than one culturable cell was calculated to be present. For example, in the experiment where about 1.7 culturable cells were present in undiluted samples, only about 0.085 culturable cells should have been present in 100-fold dilutions (of $5 \mathrm{ml}$ volume), yet recovery was obtained in three out of four cases (Table 1). The reason for this is not clear, but one possible explanation is that cells just on the transition of entry into the viable but nonculturable state are not platable on direct transfer from liquid medium at $4{ }^{\circ} \mathrm{C}$ to solid medium at room temperature, but can be plated when held at room temperature in liquid medium prior to plating. Another possibility is that a population of cells is present that is nonculturable on solid medium, but which can grow and divide in liquid medium, after temperature upshift. This would also explain the discrepancy between the increase in AODC and the increase in plate counts in the 10 - and 100-fold dilutions in Table 1. For example, plate counts in the 100 -fold dilution increased from $1.7 \times 10^{-2}$ to $4.3 \times 10^{5}$ (an increase of about $4.3 \times 10^{5}$ ) whereas AODCs increased from $8.2 \times 10^{3}$ to $1.7 \times 10^{6}$ (an increase of about $1.7 \times 10^{6}$ ). If any population of cells is present that is nonculturable on solid medium, plate counts may underestimate the total growth that has occurred and these may have been accurately measured by AODC. This does not alter our conclusion that recovery of culturable cells from temperature upshift alone appears to be dependent on cell division and growth, and not solely the result of resuscitation of viable but nonculturable cells.

Additional evidence supporting this conclusion was obtained from experiments on growth of $V$. cholerae under very low nutrient conditions. $V$. cholerae cells which had recovered after temperature upshift were inoculated, at a concentration of $2.4 \times 10^{2}$ c.f.u. $\mathrm{ml}^{-1}$, in 10 p.p.t. ASW and filter-sterilized microcosm 10 p.p.t. ASW, and grew to $6.2 \times 10^{5}$ c.f.u. $\mathrm{ml}^{-1}$ (Fig. 3). The observation that $V$. cholerae could undergo cell division in a very low nutrient medium to exhibit a thousandfold increase in cell numbers supports our conclusion that cell division occurred during recovery to culturability, after the temperature upshift. Moreover, fresh culturable $V$. cholerae cells grew to a concentration of about $10^{5}$ c.f.u. $\mathrm{ml}^{-1}$ when this strain was inoculated at low cell densities $\left(10^{2}-10^{3}\right.$ cells $\left.\mathrm{ml}^{-1}\right)$ in 10 p.p.t. $\mathrm{ASW}$ at $30^{\circ} \mathrm{C}$ (Fig. 4).

Since recovery of viable but nonculturable cells was not achieved when all the cells were nonculturable (i.e. after incubation for a further $8 \mathrm{~d}$ after no culturable cells were detectable, despite temperature upshift) we conclude that recovery of culturable cells when viable but nonculturable $V$. cholerae cells are subjected to a temperature upshift alone from $4{ }^{\circ} \mathrm{C}$ to $30^{\circ} \mathrm{C}$ may be a result of the regrowth of the few culturable cells which survive and remain in the medium, and not resuscitation of all cells from the viable but nonculturable state. The possibility has not been eliminated that resuscitation of a small number of cells occurred, and was followed by growth of these resuscitated cells. It is also possible that a resuscitationinducing factor may be produced by culturable cells that triggers resuscitation in nonculturable cells. Kaprelyants et al. (1994) found that dormant Micrococcus luteus cells were resuscitated, apparently by a factor produced by viable (platable) cells, an observation meriting further study.

\section{Concluding remarks}

An understanding of the viable but nonculturable state in $V$. cholerae is of critical importance for the purpose of monitoring the aquatic environment for this pathogen. This study indicates that, although important, temperature change alone is insufficient to bring about recovery of $V$. cholerae from the viable but nonculturable state. Hence, interpretation of results of temperature-based experiments require careful examination and interpretation. Recent work with Helicobacter pylori in our laboratory suggests that a combination of factors, including temperature and nutrient concentration, play a significant role either in combination and/or in relation to other environmental factors in recoverability from the viable but nonculturable state (Mai et al., 1990). Obviously, the physiology and molecular genetic regulation of the viable but nonculturable state in Gram-negative bacteria such as $V$. cholerae need to be elucidated.

\section{ACKNOWLEDGEMENTS}

This work was supported by Cooperative Agreement No. CR 817791-01 between the Environmental Protection Agency and the University of Maryland, and by a grant to I. T.K. from the Jeffress Memorial Trust (J-256).

This paper is contribution no. 207 from the Center of Marine Biotechnology.

\section{REFERENCES}

Allen-Austin, D., Austin, B. \& Colwell, R. R. (1984). Survival of Aeromonas salmonicida in river water. FEMS Microbiol Lett 21, 143-146.

Baker, R. M., Singleton, F. L. \& Hood, M. A. (1983). The effects of nutrient deprivation on Vibrio cholerae. Appl Environ Microbiol 46, 930-940.

Brayton, P. R. \& Colwell, R. R. (1987). Fluorescent antibody staining method for enumeration of viable environmental Vibrio cholerae 01. J Microbiol Methods 6, 309-314.

Byrd, J. J. \& Colwell, R. R. (1990). Maintenance of plasmids pBR322 and pUC8 in nonculturable Escherichia coli in the marine environment. Appl Environ Microbiol 56, 2104-2107.

Chowdhury, M. A. R., Miyoshi, S.-I., Yamanaka, H. \& Shinoda, S. (1992). Ecology and distribution of toxigenic Vibrio cholerae in aquatic environment of a temperate region. Microbios 72, 203-213.

Colwell, R. R., Brayton, P. R., Grimes, D. J., Roszack, D. R., Huq, S. A. \& Palmer, L. M. (1985). Viable, but non-culturable, Vibrio cholerae and related pathogens in the environment: implications for release of genetically engineered microorganisms. Bio/Technology 3 , 817-820.

Colwell, R. R., Tamplin, M. L., Brayton, P. R., Gauzens, A. L., Tall, B. D., Harrington, D., Levine, M. M., Hall, S., Huq, A. \& Sack, D. A. 
(1990). Environmental aspects of $V$. cholerae in transmission of cholera. In Advances in Research on Cholera and Related Areas, pp. 327-343. Edited by R. B. Sack \& Y. Zinnaka. Tokyo: KTK Scientific Publishers.

Epstein, P. R., Ford, T. E. \& Colwell, R. R. (1993). Marine ecosystems. Lancet 342, 1216-1219.

Hobbie, J. E., Daleu, R. J. \& Jasper, S. (1977). Use of nucleopore filters for counting bacteria by fluorescence microscopy. Appl Environ Microbiol 33, 1225-1228.

Islam, S., Hasan, M. K., Miah, M. A., Sur, G. C., Felsenstein, A., Venkatesan, M., Sack, R. B. \& Albert, M. J. (1993). Use of the polymerase chain reaction and fluorescent-antibody methods for detecting viable but nonculturable Shigella dysenteriae type 1 in laboratory microcosms. Appl Environ Microbiol 59, 536-540.

Kaper, J. B., Lockman, H., Baldini, M. M. \& Levine, M. M. (1984). A recombinant live oral cholera vaccine. Bio/ Technology 2, 345-349.

Kaprelyants, A. S. \& Kell, D. B. (1993). Dormancy in stationaryphase cultures of Micrococcus luteus: flow cytometric analysis of starvation and resuscitation. Appl Environ Microbiol 59, 3187-3196.

Kaprelyants, A. S., Mukamolova, G. V. \& Kell, D. B. (1994). Estimation of dormant Micrococcus luteus cells by penicillin lysis and by resuscitation in cell-free spent culture medium at high dilution. FEMS Microbiol Lett 115, 347-352.

Kogure, K., Simidu, U. \& Taga, N. (1979). A tentative direct microscopic method for counting living marine bacteria. Can $J$ Microbiol 25, 415-420.

Linder, K. \& Oliver, J. D. (1989). Membrane fatty acid and virulence changes in the viable but non culturable state of Vibrio vulnificus. Appl Environ Microbiol 55, 2837-2842.

Mai, U. E. H., Shahamat, M. \& Colwell, R. R. (1990). Survival of Helicobacter pylori in the aquatic environment. In Helicobacter pylori 1990, pp. $90-96$. Edited by H. Menge, M. Gregor, G. N. J. Tytgat, B. J. Marshal \& C. A. M. McNulty. Berlin: Springer-Verlag.

Maniatis, T., Fritsch, E. F. \& Sambrook, J. (1982). Molecular Cloning: a Laboratory Manual. Cold Spring Harbor, NY: Cold Spring Harbor Laboratory.

Nilsson, L., Oliver, J. D. \& Kjelleberg, S. (1991). Resuscitation of Vibrio vulnificus from the viable but not culturable state. $J$ Bacteriol 173, 5054-5059.
Peele, E. R. \& Colwell, R. R. (1981). Application of a direct microscopic method for enumeration of substrate-responsive marine bacteria. Can J Microbiol 27, 1071-1075.

Rahman, I., Shahamat, M., Kirchman, P. A., Russek-Cohen, E. \& Colwell, R. R. (1994). Methionine uptake and cytopathogenicity of viable but nonculturable Shigella dynsenteriae type I. Appl Environ Microbiol 60, 3573-3578.

Rodriguez, G. G., Phipps, D., Ishiguro, K. \& Ridgway, H. F. (1992). Use of fluorescent redox probe for direct visualization of actively respiring bacteria. Appl Environ Microbiol 58, 1801-1808.

Rollins, D. M. \& Colwell, R. R. (1986). Viable but nonculturable stage of Campylobacter jejuni and its role in survival in the natural aquatic environment. Appl Environ Microbiol 52, 531-538.

Roszak, D. B. \& Colwell, R. R. (1987). Survival strategies of bacteria in the natural environment. Microbiol Rev 51, 365-379.

Roszak, D. B., Grimes, D. J. \& Colwell, R. R. (1984). Viable but nonrecoverable stage of Salmonella enteritidis in aquatic systems. Can J Microbiol 30, 334-338.

Shahamat, M., Mai, U., Paszko-Kolva, C., Kessel, M. \& Colwell, R. R. (1993). Use of microautoradiography to assess viability of Helicobacter pylori in water. Appl Environ Microbiol 59, 1231-1235.

Weichart, D., Oliver, J. D. \& Kjelleberg, S. (1992). Low temperature induced non-culturability and killing of Vibrio vulnificus. FEMS Microbiol Lett 100, 205-210.

Wolf, P. W. \& Oliver, J. D. (1992). Temperature effects on the viable but nonculturable state of Vibrio vulnificus. FEMS Microbiol Lett 101, 33-39.

Xu, H.-S., Roberts, N., Singleton, F. L., Attwell, R. W., Grimes, D. J. \& Colwell, R. R. (1982). Survival and viability of nonculturable Eschericbia coli and Vibrio cholerae in the estuarine and marine environment. Microb Ecol 8, 313-323.

Zimmermann, R., Iturriaga, R. \& Becker-Birck, J. (1978). Simultaneous determination of the total number of aquatic bacteria and the number thereof involved in respiration. Appl Environ Microbiol 36, 926-935.

Received 5 October 1994; accepted 21 October 1994. 